\title{
The Effect of Volatile Oil from Vernonia anthelmintica Seeds on Melanin Synthesis in B16 Cells and Its Chemical Analysis by GC-QTOF-MS
}

\author{
Abulikemu Aobuli (D, , ${ }^{1,2}$ Jumai Maitusong, ${ }^{2,3}$ Mahinur Bakri, ${ }^{1,3}$ Xueying Lu, ${ }^{1}$ \\ Maitinuer Maiwulanjiang $\mathbb{D}^{1,3}$ and Haji Akber Aisa $\mathbb{D}^{1}$
${ }^{1}$ The Key Laboratory of Plant Resources and Chemistry of Arid Zone, Xinjiang Technical Institute of Physics and Chemistry, Chinese Academy of Sciences, Urumqi 830011, China
${ }^{3}$ State Key Laboratory Basis of Xinjiang Indigenous Medicinal Plants Resource Utilization, Xinjiang Technical Institute of Physics and Chemistry, Chinese Academy of Sciences, Urumqi 830011, China \\ ${ }^{2}$ University of The Chinese Academy of Sciences, Beijing 100039, China
}

Correspondence should be addressed to Maitinuer Maiwulanjiang; mavlanjan@ms.xjb.ac.cn and Haji Akber Aisa; haji@ms.xjb.ac.cn

Received 22 March 2018; Accepted 25 July 2018; Published 7 August 2018

Academic Editor: Francisco Solano

Copyright (C) 2018 Abulikemu Aobuli et al. This is an open access article distributed under the Creative Commons Attribution License, which permits unrestricted use, distribution, and reproduction in any medium, provided the original work is properly cited.

\begin{abstract}
Vernonia anthelmintica Willd. seeds have been used in folk medicine for the treatment of leukoderma in Xinjiang, China, for more than 300 years. The promoting activities of its volatile oil (AVO) in melanogenesis and its chemical composition were investigated in this paper. The bioactivities of AVO were examined by melanin synthesis and tyrosinase activity assay in B16 cells. Using GCQTOF-MS technology, each compound of AVO contains a single separated peak in GC and the retention indices of every GC peak were calculated by the retention times of C7 C30 n-alkanes that were injected at the same chromatographic conditions. Then each individual peak was identified by comparing its mass spectrum with the MS library (NIST 14). As a result, AVO increased the melanin content and tyrosinase activity in a dose-dependent manner at concentrations of $10-30 \mu \mathrm{g} \cdot \mathrm{mL}^{-1}$. The $64 \mathrm{compounds}$ were identified in AVO which occupied $95.15 \%$ of total peak area in GC. They mainly contained caryophyllene (23.73\%), sabinene (18.15\%), $\alpha$-thujene (6.57\%), thymol (5.29\%), 4-epi- $\alpha$-acoradiene (4.98\%), limonene (4.92\%), anethole (3.44\%), etc. According to the results the AVO can promote melanogenesis and upregulate tyrosinase activity in B16 cells.
\end{abstract}

\section{Introduction}

Vernonia anthelmintica Willd., a member of the family Asteraceae, is an erect forb or shrub where more than 1000 species of the genus Vernonia were widely distributed in subtropical and tropical areas throughout Asia and Africa [1-3]. In traditional Uyghur medicine (TUM), seeds of the Vernonia anthelmintica Willd. ( $V$. anthelmintica) were used as a herbal medicine with the common name of "Kaliziri" for the treatment of diabetes mellitus, leukoderma, skin disease, fever, worm infection, and kidney trouble [4].

In recent years with the development of traditional medicine in China, V. anthelmintica has been widely used in the medicinal formula for the treatment of vitiligo, such as "Kursi babuqi" and "Injection of Kaliziri." Wang et al. [5] treated 157 patients with "Kursi babuqi" for three months and that showed that effective rate of treatment group was $56 \%$. Liu et al. [6] reported that 445 patients of vitiligo vulgaris were treated with "Kursi babuqi" for one year, and effectiveness of treatment reached $93.5 \%$. For the other formulation of $V$. anthelmintica, "injection of Kaliziri" was applied to the patient combined with UV treatment, and effective rate of treatment group was 70.4\% [7]. The herb also was recorded in the book of "Ministry of PRC Health and Drug standards" $[8,9]$ and also was recorded with various biological effects, including antiarthritic [1], antibacterial, anthelmintic, 
analgesic, anti-inflammatory, antioxidant, antidiabetic, antihyperlipidemic, and cytotoxic activities [10-15].

Previous phytochemical investigations of the herb have shown that it contains flavones [16], caffeoylquinic acid derivatives [17], sesquiterpene, triterpenoids, elemanolide sesquiterpenoids, and guaianolide sesquiterpenoids [1]. It was reported that few compounds were isolated from the herb which able to promote melanin synthesis activity $[18,19]$.

Although many researches about $V$. anthelmintica seeds were found, no more scientific results were reported about the chemical composition and bioactivity of volatile oil from $V$. anthelmintica seeds (AVO). To search active components for the treatment of vitiligo we studied volatile components of $V$. anthelmintica and its bioactivities. In this research, we studied the AVO effects on melanogenesis in B16 cells and investigated its chemical composition by GC-QTOF-MS method.

\section{Materials and Methods}

2.1. Plant Material. The seeds of $V$. anthelmintica (batch number: Z30031501) were purchased in March 2016, from Xinjiang Meditsina Uyghur pharmaceutical Co., Ltd, Xinjiang, China. Voucher specimen has been deposited at the herbarium (Voucher no. WY02316), Xinjiang Institute of Ecology and Geography. Plant materials were identified by Professor Feng Ying from Xinjiang Institute of Ecology and Geography, Chinese Academy of Science.

2.2. Reagents. DMSO (D8418) was purchased from SigmaAldrich (St. Louis, MO, USA). A cell counting kit (FC101) was purchased from TransGen Biotechnology (Beijing, China). C7-C30 saturated alkanes standard 1ml (SUPELCO, USA), nhexane (analytical grade).

2.3. Extraction and Sample Preparation. The powdered V. anthelmintica seeds $(100 \mathrm{~g})$ were extracted by volatile oil extractor with $1400 \mathrm{~mL}$ water for $6 \mathrm{~h}$. The oil was collected and dried over anhydrous sodium sulfate and dissolved in dimethyl sulfoxide (DMSO) to make a stock solution and then stored at $-20^{\circ} \mathrm{C}$ until use. $50 \mathrm{mg} \cdot \mathrm{mL}^{-1}$ stock solution of AVO in DMSO was used for cell experiment. Fourfold dilution of AVO with $n$-hexane was used for chemical analysis.

2.4. Cell Culture. The murine B16 melanoma cells were purchased from the Type Culture Collection of the Chinese Academy of Sciences (Shanghai, China, No. TCM2) and were cultured in high glucose Dulbecco's modified eagle medium (HG-DMEM, Gibco) supplemented with 10\% FBS (BI, Biological Industries), $100 \mu \mathrm{g} \bullet \mathrm{mL}^{-1}$ streptomycin, and $100 \mathrm{U} \cdot \mathrm{mL}^{-1}$ penicillin (Gibco, Cat. No. 15140-122). The cells were maintained in a humidified incubator with $5 \% \mathrm{CO} 2$ at $37^{\circ} \mathrm{C}$, and they were subcultured every 2 days to maintain logarithmic growth.

2.5. Cell Viability Assay. The viability of cultured B16 cells was assayed by adding CCK- 8 solution. Generally, B16 cells were plated in 96-well plate at a density of $5 \times 10^{3}$ cells per well and incubated for $24 \mathrm{~h}$. Test samples were added with different concentration, and the cells were incubated for $24 \mathrm{~h}$. After discarding the culture medium of the cells, $10 \mu \mathrm{L}$ of CCK- 8 solution was added into each well and the cells were incubated at $37^{\circ} \mathrm{C}$ for $2 \mathrm{~h}$. The absorbance was determined at $450 \mathrm{~nm}$ using microplate spectrophotometer (Spectra Max M5, Molecular Devices Company, Sunnyvale, CA, USA). The absorbance of cells without treatment was regarded as $100 \%$ of cell survival. Each treatment was performed in triplicate, and each experiment was repeated for three times.

2.6. Melanin Content Assay. The B16 cells were seeded in a six-well plate $\left(2 \times 10^{5}\right.$ cells/ well $)$ for $12 \mathrm{~h}$, after renewing the culture medium of the cells treated with different concentrations of AVO for $48 \mathrm{~h}$ and washed with ice-cold PBS twice. Cells were lysed [16], and each lysate was taken $150 \mu \mathrm{l}$ into a 96-well plate and measured; optical density of the solubilized melanin was measured at $405 \mathrm{~nm}$ by a multiplate reader. BCA Protein Assay Kit (Biomed, Beijing, China) was used to determine the protein concentration of each sample. The melanin content was normalized to the cellular protein concentration (abs melanin/ $\mu$ g protein). The percentage value of the AVO treated cells was calculated with respect to the negative control [20].

2.7. Tyrosinase Activity Assay. The tyrosinase activity was estimated by measuring the rate of L-DOPA oxidation [21, 22]. B16 cells were seeded in a six-well plate at a density of $3 \times 10^{5}$ cells per well and allowed to attach for $12 \mathrm{~h}$. Cultured B16 cells were incubated in the absence or presence of AVO for $24 \mathrm{~h}$, and the adherent cells were washed with ice-cold PBS twice and lysed with $100 \mu \mathrm{L}$ lysis buffer (1\% sodium deoxycholate and $1 \%$ TritonX-100 in PBS) for $30 \mathrm{~min}$ at $80^{\circ} \mathrm{C}$, and each lysate was centrifuged at $12,000 \times \mathrm{g}$ for 15 min to obtain the supernatant. Ninety microliters $(90 \mu \mathrm{L})$ of the supernatant was added to $10 \mu \mathrm{L}$ of freshly prepared 10 $\mathrm{mmol} \cdot \mathrm{mL}^{-1} \mathrm{~L}$-DOPA solution in each well of a 96-well plate. Then, the cells were incubated at $37^{\circ} \mathrm{C}$ in dark for $30 \mathrm{~min}$ and the absorbance of dopachrome was measured at $490 \mathrm{~nm}$ using a microplate reader. Data was calculated using the following formula: tyrosinase activity (\%) $=(O D 490$ of sample/OD 490 of control) $\times 100$.

2.8. GC-QTOF-MS Analysis. For the chemical analysis of AVO, an Agilent 7200 GC-QTOF-MS (Agilent, SantaClara, USA) was used, equipped with a HP-INNOWax capillary column (Agilent, $60 \mathrm{~m} \times 0.25 \mathrm{~mm}$ i.d., $0.25 \mu \mathrm{m}$ film thickness, polyethylene glycol stationary phase). The carrier gas was $99.99 \%$ high purity Helium with a flow rate of $0.8 \mathrm{~mL} \cdot \mathrm{min}^{-1}$. GC injection was performed in pulsed split mode (split rate 10:1, purge flow to split vent $5 \mathrm{ML} \cdot \mathrm{min}^{-1}$ ). The following GC temperature gradient was used: $60^{\circ} \mathrm{C}$ for $2 \mathrm{~min}, 2^{\circ} \mathrm{C} / \mathrm{min}$ to $80^{\circ} \mathrm{C}, 8^{\circ} \mathrm{C} / \mathrm{min}$ to $180^{\circ} \mathrm{C}, 4^{\circ} \mathrm{C} / \mathrm{min}$ to $240^{\circ} \mathrm{C}$, and holding at $240^{\circ} \mathrm{C}$ for $30 \mathrm{~min}$. The temperatures of the injector, the transfer line, and the ion source were set to 250,280 , and $230^{\circ} \mathrm{C}$, respectively. The total run time was $65 \mathrm{~min}$ with a solvent delay of $5 \mathrm{~min}$. The QTOF mass spectrum was recorded at five scans per second with a mass-to-charge ratio $50-500 \mathrm{~m} / \mathrm{z}$ mass acquisition range. Ionization was operated 
in electron impact ionization (EI) mode at $70 \mathrm{eV} .1 .2 \mu \mathrm{L}$ AVO sample solution was injected in to GC-QTOF-MS system for analysis, in the same chromatographic conditions that C7C30 n-alkanes standard used for calculating the retention times indices of GC peak from sample (Supplementary Figure 2) $[23,24]$.

2.9. Data Analysis. The results of cell experiment were expressed as the mean $\pm \mathrm{SD}$, and the statistical analysis was performed by one-way ANOVA followed by a Tukey post hoc test for multiple comparison tests. Significant differences were accepted when $\mathrm{P}<0.05$. The retention indices (I) of every GC peaks were calculated with retention times of C7-C30 n-alkanes standard that were injected at the same chromatographic conditions. Then, the mass spectral data were processed using Mass Hunter Qualitative Analysis B.070. The compounds were identified by comparing with mass spectra NIST14. L library data [23] and validated with the published compounds index data. The relative percentage of compounds was normalized by peak area.

$$
I=100 \times \frac{\lg t^{\prime}(i)-\lg t^{\prime}(n)}{\lg t^{\prime}(n+1)-\lg t^{\prime}(n)}
$$

where $I$ is the retention index of the components to be tested and $(i)$ is the adjusted retention time ( $\mathrm{min}$ ) of the components to be tested; $n$ and $n+1$ are the carbon amounts of $n$-alkanes before and after the unknowns effused, respectively; $t^{\prime}(n)$ and $t^{\prime}(n+1)$ are the No. $n$ and No. $n+1$ carbon retention times of $n$-alkanes, respectively $[25,26]$.

\section{Results}

3.1. Cell Viability of Melanoma Cells Induced by AVO. Our results showed that murine melanoma B16 cells treated with concentration of $1-10 \mu \mathrm{g} \cdot \mathrm{mL}^{-1}$ AVO for $24 \mathrm{~h}$ did not induce any changes in cell viability. At the concentration of 10 $30 \mu \mathrm{g} \cdot \mathrm{mL}^{-1}$, the cell viability was around 80 to 90 percent which display slight cytotoxicity. Compared with untreated cells, with the treatment of $50 \mu \mathrm{g} \cdot \mathrm{mL}^{-1}$ of AVO cell viability was only 56 percent and indicated relative higher cytotoxicity (Figure 1). Therefore, the concentrations at $10-30 \mu \mathrm{g} \cdot \mathrm{mL}^{-1}$ are suitable for further evaluating the effects of AVO on tyrosinase activity and melanin synthesis in B16 cells.

3.2. AVO Enhances Intracellular Melanin Content and Tyrosinase Activity. In the melanin content assay, the absorbance of the same number of cells across AVO concentrations (10$30 \mu \mathrm{g} \cdot \mathrm{mL}^{-1}$ ) was measured in order to exclude the possibility that a rise in melanin content may be induced by the cell proliferating effect of AVO. We found that melanin levels were increased in B16 cells in a dose-dependent manner after the treatment of AVO (Figure 2(a)). At the concentration of $10-30 \mu \mathrm{g} \cdot \mathrm{mL}^{-1}$, the melanin content showed concentration-dependent increase, while the concentration of $20-30 \mu \mathrm{g} \cdot \mathrm{mL}^{-1}$ showed significant increase in melanin content. The effect of AVO on tyrosinase activity did not show significant difference compared with untreated group (Figure 2(b)); however it showed a rise trend.

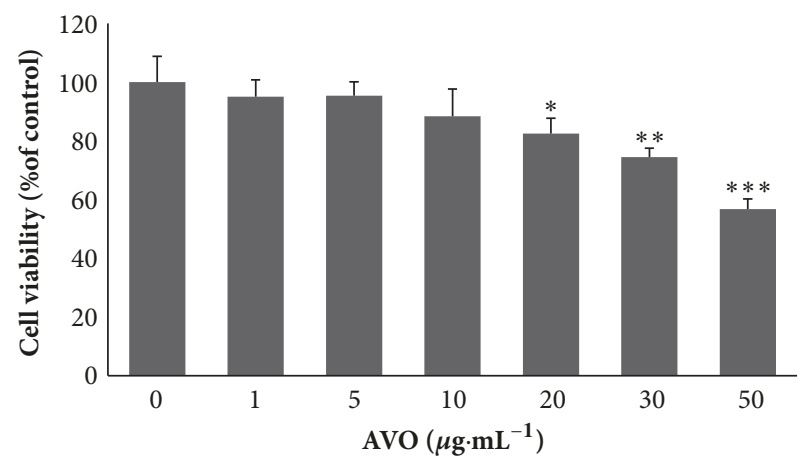

FIGURE 1: B16 melanoma cells were exposed to various concentrations of $\operatorname{AVO}\left(1,5,10,20,30\right.$, and $\left.50 \mu \mathrm{g} \cdot \mathrm{mL}^{-1}\right)$ for $24 \mathrm{~h}$. Cell viability was measured by a CCK- 8 assay. The data are shown as the means \pm $\mathrm{SD} ; n=3$.

3.3. GC-QTOF-MS Analysis. The result of AVO was obtained at a yield of $0.15 \% \mathrm{w} / \mathrm{w}$. The 86 peaks were separated in GC as shown Figure 3 and preliminarily identified 64 compounds by QTOF-MS which account for $95.15 \%$ of total peak area (Table 1). According to the chemical composition analysis of AVO, the terpenoids accounted for $73.53 \%$, phenolics $8.07 \%$, ethers $5.31 \%$, esters $3.76 \%$, hydrocarbons $3.54 \%$, aromatics $0.42 \%$, ketones $0.39 \%$, and acids $0.15 \%$. The main chemical components of AVO were caryophyllene $23.73 \%$, sabinen $18.15 \%$, $\alpha$-thujene $6.57 \%$, thymol $5.29 \%$, limonene $4.92 \%$, and 4 -epi- $\alpha$-acoradiene $4.98 \%$.

\section{Discussion}

Vitiligo is an acquired, progressive, multifactorial, and depigmentation disorder characterized by the appearance of circumscribed white macules in the skin caused by chronic, progressive loss of functional melanocytes in the epidermis $[27,28]$. The etiology of vitiligo is poorly understood. Also, the numerous factors have been implicated in the development of vitiligo, including trauma, stress, exposure to sunlight for long time, skin infections, neural stress, cancer, melatonin receptors dysfunction, some drugs, and endocrine diseases and toxic compounds. These causal factors may act independently or in concert [29]. The pigmentation of the skin provides many valuable function; perhaps foremost among these is the photo protection of underlying tissues from ultraviolet (UV) radiation. Melanocytes respond to a wide variety of intrinsic and extrinsic factors produced by the environment or by neighboring cells in the skin, including UV, stimulating hormone (MSH), agouti signal protein (ASP), endothelin 1 (ET1), dickkopf 1 (DKK1), a wide variety of growth factors, and cytokines [4]. Melanin biosynthesis is catalyzed by three melanocyte-specific enzymes: TYR, tyrosinase-related protein 1 (TRP-1), and TRP-2 [4]. The tyrosinase playing an essential role in melanocyte melanin biosynthesis has been known for many decades. Therefore, tyrosinase is an important index for the treatment and diagnosis of vitiligo. In our result the AVO increased the melanin synthesis and slightly impacted tyrosinase activity but did not make a significant difference with untreated 


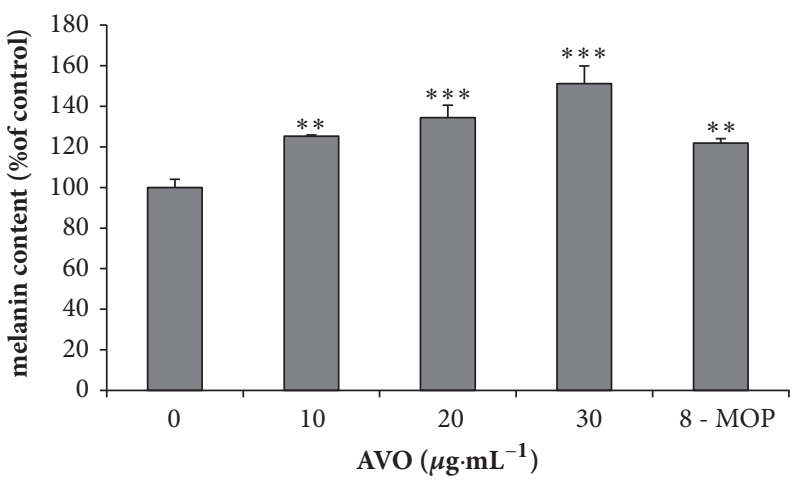

(a)

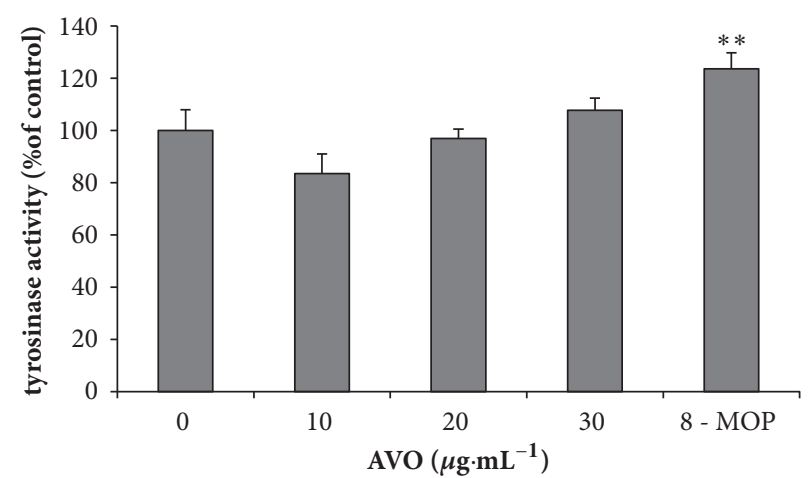

(b)

FIGURE 2: Cellular melanin synthesis (a) in B16 melanoma cells and concentration-dependent effect of AVO on tyrosinase activity (b). Cells were treated with $0.1 \%$ DMSO as a vehicle or with AVO at 10,20 , and $30 \mu \mathrm{g} \cdot \mathrm{mL}^{-1}$ and $50 \mu \mathrm{M} 8-\mathrm{MOP}$ as a positive control. The data of melanin content is shown (a). The cells were then analyzed by tyrosinase activity assay (b). Each percentage value for treated cells is reported relative to that of $0.1 \%$ DMSO cells. The results have been shown as the means $\pm \mathrm{SD} ; \mathrm{n}=3, * * \mathrm{p}<0.01$, and $* * * \mathrm{p}<0.001$ compared with $0.1 \%$ DMSO cells.

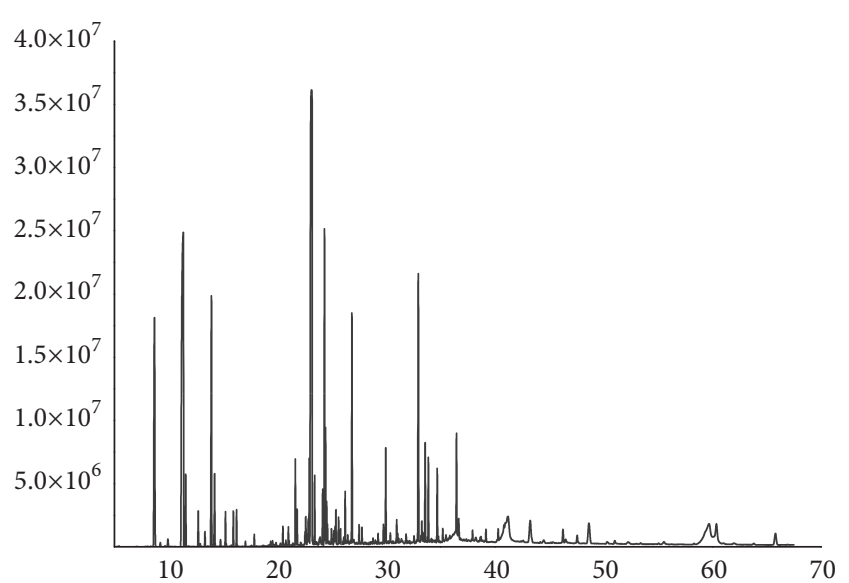

Figure 3: The GC peak spectra of AVO.

group, so, we considered that AVO can promote melanin biosynthesis may relate with other enzyme (TRP-1, TRP-2). It provided potential research value.

Melanocyte loss and its underlying pathogenic mechanisms are not fully understood [30]. Both intrinsic (gene polymorphisms/mutations, autoimmunity, autotoxicity of melanocytes, and oxidative stress) and extrinsic factors are known to contribute to vitiligo, and it is recognized that hypersensitivity to oxidative stress has an important role in ultimate destruction of epidermal melanocytes. Oxidative stress has been demonstrated to be enhanced in pathological melanocytes and closely related to melanocyte apoptosis and autoimmune destruction [31-36]. Our preliminary result also suggests that AVO could protect $\mathrm{B} 16$ cells from $\mathrm{H}_{2} \mathrm{O}_{2}$ induced oxidative damage (Supplementary Figure 1).

As volatiles, AVO was characterized by a strong odor. It is synthesized by plants as secondary metabolites and has been widely used owing to its bactericidal, virucidal, fungicidal, antiparasitic, insecticidal, anticancer, antioxidant, antidiabetic and cardiovascular effects [37]. The AVO was mainly composed of terpenoids occupying $73.53 \%$ of total chemical content, such as caryophyllene, sabinene, and limonene. Being natural compounds, the terpenoids were shown to have wide range of biological and pharmacological activities, including central effects, antimicrobial, and antitumor actions $[38,39]$. In our results, high concentrations of AVO showed little cytotoxic properties in melanocytes. Therefore, we observed the protective effect of AVO on $\mathrm{H}_{2} \mathrm{O}_{2}$ induced $\mathrm{B} 16$ cells injury. Result showed that pretreatment of AVO reduced $\mathrm{H}_{2} \mathrm{O}_{2}$-induced cell injury in a dose-dependent manner (supplementary Figure 1). From our result, we tentatively conclude that AVO could protect melanocytes from harmful factors in vitiligo like oxidative stress. This result is similar to the antitumor and antioxidant effect of terpenoids. So, we considered that the terpenoids were major biologically active compounds in AVO. Since AVO had possessed terpenoids such as caryophyllene, sabinen, 4epi- $\alpha$-acoradiene, $\alpha$-thujene, and limonene, it is hypothesized that the unsaturated double bond in active ingredients of AVO may be responsible for its antioxidant properties (Figure 4). Caryophyllene as a main content in AVO provided extensive pharmacological effects. Dahham et al. [37] reported that compounds have anticancer, antioxidant, and antimicrobial activities. They observed the antiproliferative effect of caryophyllene on the cancer cell lines. Among the tested cancer cells, the compound demonstrated selective antiproliferative effect against three cancer cell lines, namely, HCT 116, PANC-1, and HT29 cells, whereas it exhibited either moderate or poor cytotoxic effects against ME-180, PC3, K562, and MCF-7. Noteworthily, the compound displayed low toxicity against the normal cell lines such as 3T3-L1 and RGC-5. The study concluded that caryophyllene has strong selective cytotoxic properties against human colorectal cancer cells. Based on this report and our result of AVO cell viability assay, we considered that caryophyllene may be responsible for AVO's biological effect. In addition, we employed the TCMSP database to check the ADME 
TABLE 1: Volatile compositions in AVO.

\begin{tabular}{|c|c|c|c|c|c|}
\hline & Compound & $\mathrm{RT}(\min )$ & Possible formula & $\mathrm{RI}$ & Content (\%) \\
\hline 1 & $\alpha$-Thujene & 8.68 & $\mathrm{C}_{10} \mathrm{H}_{16}$ & 1029 & 6.57 \\
\hline 2 & Toluene & 9.22 & $\mathrm{C}_{7} \mathrm{H}_{8}$ & 1049 & 0.08 \\
\hline 3 & Camphene & 9.92 & $\mathrm{C}_{10} \mathrm{H}_{16}$ & 1075 & 0.17 \\
\hline 4 & Sabinene & 11.34 & $\mathrm{C}_{10} \mathrm{H}_{16}$ & 1124 & 18.15 \\
\hline 5 & $\beta$-Thujene & 11.56 & $\mathrm{C}_{10} \mathrm{H}_{16}$ & 1131 & 1.08 \\
\hline 6 & $\alpha$-Phellandrene & 12.71 & $\mathrm{C}_{10} \mathrm{H}_{16}$ & 1169 & 0.53 \\
\hline 7 & $\alpha$-Terpine & 13.33 & $\mathrm{C}_{10} \mathrm{H}_{16}$ & 1189 & 0.22 \\
\hline 8 & Limonene & 13.92 & $\mathrm{C}_{10} \mathrm{H}_{16}$ & 1209 & 4.92 \\
\hline 9 & Eucalyptol & 14.21 & $\mathrm{C}_{10} \mathrm{H}_{18} \mathrm{O}$ & 1219 & 1.23 \\
\hline 10 & Methoxyacetic acid,4-tetradecyl ester & 14.76 & $\mathrm{C}_{17} \mathrm{H}_{34} \mathrm{O}_{3}$ & 1239 & 0.11 \\
\hline 11 & $\gamma$-Terpinene & 15.22 & $\mathrm{C}_{10} \mathrm{H}_{16}$ & 1255 & 0.48 \\
\hline 12 & o-Cymene & 15.94 & $\mathrm{C}_{10} \mathrm{H}_{14}$ & 1281 & 0.47 \\
\hline 13 & Terpinolene & 16.24 & $\mathrm{C}_{10} \mathrm{H}_{16}$ & 1292 & 0.47 \\
\hline 14 & Isomenthone & 20.5 & $\mathrm{C}_{10} \mathrm{H}_{18} \mathrm{O}$ & 1481 & 0.28 \\
\hline 15 & Copaene & 21.00 & $\mathrm{C}_{15} \mathrm{H}_{24}$ & 1507 & 0.22 \\
\hline 16 & Linalyl acetate & 21.64 & $\mathrm{C}_{12} \mathrm{H}_{20} \mathrm{O}_{2}$ & 1543 & 0.94 \\
\hline 17 & $\alpha$-Gurjunene & 21.80 & $\mathrm{C}_{15} \mathrm{H}_{24}$ & 1552 & 0.47 \\
\hline 18 & Fenchol & 22.53 & $\mathrm{C}_{10} \mathrm{H}_{18} \mathrm{O}$ & 1593 & 0.17 \\
\hline 19 & $\beta$-Elemene & 22.6 & $\mathrm{C}_{15} \mathrm{H}_{24}$ & 1596 & 0.43 \\
\hline 20 & cis-Caryophyllene & 22.83 & $\mathrm{C}_{15} \mathrm{H}_{24}$ & 1610 & 0.45 \\
\hline 21 & L-terpinen-4-ol & 22.92 & $\mathrm{C}_{10} \mathrm{H}_{18} \mathrm{O}$ & 1615 & 0.99 \\
\hline 22 & Caryophyllene & 23.14 & $\mathrm{C}_{15} \mathrm{H}_{24}$ & 1628 & 23.73 \\
\hline 23 & dl-Menthol & 23.42 & $\mathrm{C}_{10} \mathrm{H}_{20} \mathrm{O}$ & 1645 & 0.83 \\
\hline 24 & Ginsinsene & 24.16 & $\mathrm{C}_{15} \mathrm{H}_{24}$ & 1689 & 0.86 \\
\hline 25 & 4 -epi- $\alpha$-Acoradiene & 24.32 & $\mathrm{C}_{15} \mathrm{H}_{24}$ & 1699 & 4.98 \\
\hline 26 & $\alpha$-Terpinyl acetate & 24.42 & $\mathrm{C}_{12} \mathrm{H}_{20} \mathrm{O}_{2}$ & 1705 & 1.38 \\
\hline 27 & Chamigren & 24.52 & $\mathrm{C}_{15} \mathrm{H}_{24}$ & 1711 & 0.51 \\
\hline 28 & $\beta$-Selinene & 24.6 & $\mathrm{C}_{15} \mathrm{H}_{24}$ & 1716 & 0.22 \\
\hline 29 & Valencene & 24.96 & $\mathrm{C}_{15} \mathrm{H}_{24}$ & 1738 & 0.20 \\
\hline 30 & Eremophilene & 25.06 & $\mathrm{C}_{15} \mathrm{H}_{24}$ & 1743 & 0.09 \\
\hline 31 & Bicyclogermacrene & 25.18 & $\mathrm{C}_{15} \mathrm{H}_{24}$ & 1750 & 0.18 \\
\hline 32 & $\delta$-Selinene & 25.22 & $\mathrm{C}_{15} \mathrm{H}_{24}$ & 1753 & 0.11 \\
\hline 33 & Piperitone & 25.3 & $\mathrm{C}_{10} \mathrm{H}_{16} \mathrm{O}$ & 1758 & 0.26 \\
\hline 34 & (-)-Carvone & 25.37 & $\mathrm{C}_{10} \mathrm{H}_{14} \mathrm{O}$ & 1762 & 0.46 \\
\hline 35 & $\delta$-Cadinene & 25.62 & $\mathrm{C}_{15} \mathrm{H}_{24}$ & 1777 & 0.33 \\
\hline 36 & Octadecane & 25.81 & $\mathrm{C}_{18} \mathrm{H}_{38}$ & 1788 & 0.20 \\
\hline 37 & Cuminal & 26.22 & $\mathrm{C}_{10} \mathrm{H}_{12} \mathrm{O}$ & 1813 & 0.70 \\
\hline 38 & $\alpha$-Terpinen-7-al & 26.46 & $\mathrm{C}_{10} \mathrm{H}_{14} \mathrm{O}$ & 1827 & 0.14 \\
\hline 39 & Anethole & 26.85 & $\mathrm{C}_{10} \mathrm{H}_{12} \mathrm{O}$ & 1849 & 3.44 \\
\hline 40 & 2-Methyloctadecane & 27.51 & $\mathrm{C}_{19} \mathrm{H}_{40}$ & 1888 & 0.21 \\
\hline 41 & Isosafrole & 27.77 & $\mathrm{C}_{10} \mathrm{H}_{10} \mathrm{O}_{2}$ & 1903 & 0.21 \\
\hline 42 & Alloaromadendrene oxide-(2) & 29.74 & $\mathrm{C}_{15} \mathrm{H}_{24} \mathrm{O}$ & 2015 & 0.27 \\
\hline 43 & Caryophyllene oxide & 29.96 & $\mathrm{C}_{15} \mathrm{H}_{24} \mathrm{O}$ & 2026 & 1.39 \\
\hline 44 & Globulol & 30.96 & $\mathrm{C}_{15} \mathrm{H}_{26} \mathrm{O}$ & 2081 & 0.35 \\
\hline 45 & Phenol, 2-methoxy-4-propyl- & 31.83 & $\mathrm{C}_{10} \mathrm{H}_{14} \mathrm{O}_{2}$ & 2128 & 0.16 \\
\hline 46 & Thunbergene & 32.56 & $\mathrm{C}_{20} \mathrm{H}_{32}$ & 2167 & 0.11 \\
\hline 47 & Thymol & 32.95 & $\mathrm{C}_{10} \mathrm{H}_{14} \mathrm{O}$ & 2187 & 5.29 \\
\hline 48 & Verticiol & 33.27 & $\mathrm{C} 20 \mathrm{H} 34 \mathrm{O}$ & 2205 & 0.30 \\
\hline 49 & Hexadecanoic acid, methyl ester & 33.45 & $\mathrm{C}_{17} \mathrm{H}_{34} \mathrm{O}_{2}$ & 2214 & 0.11 \\
\hline 50 & Carvacrol & 33.58 & $\mathrm{C}_{10} \mathrm{H}_{14} \mathrm{O}$ & 2221 & 1.62 \\
\hline 51 & Isophyllocladen & 33.88 & $\mathrm{C}_{20} \mathrm{H}_{32}$ & 2236 & 1.25 \\
\hline 52 & Cembrene A & 34.69 & $\mathrm{C}_{20} \mathrm{H}_{32}$ & 2279 & 1.09 \\
\hline 53 & 2,4-Di-tert-butylphenol & 35.2 & $\mathrm{C}_{14} \mathrm{H}_{22} \mathrm{O}$ & 2305 & 0.17 \\
\hline
\end{tabular}


TABle 1: Continued.

\begin{tabular}{|c|c|c|c|c|c|}
\hline & Compound & $\mathrm{RT}(\min )$ & Possible formula & RI & Content (\%) \\
\hline 54 & $\alpha$-Pinacene & 36.46 & $\mathrm{C}_{20} \mathrm{H}_{32}$ & 2371 & 1.57 \\
\hline 55 & Dill apiol & 36.66 & $\mathrm{C}_{12} \mathrm{H}_{14} \mathrm{O}_{4}$ & 2382 & 0.33 \\
\hline 56 & 8,11,13-triene-18-Norabieta & 37.94 & $\mathrm{C}_{19} \mathrm{H}_{28}$ & 2446 & 0.16 \\
\hline 57 & $3,3,4,5,5,8$-Hexamethyl-3,5,6,7-tetrahydro-S-indacen-1 $(2 \mathrm{H})$-one & 39.17 & $\mathrm{C}_{18} \mathrm{H}_{24} \mathrm{O}$ & 2507 & 0.20 \\
\hline 58 & $\gamma$-Thujaplicine & 40.29 & $\mathrm{C}_{10} \mathrm{H}_{12} \mathrm{O}_{2}$ & 2556 & 0.19 \\
\hline 59 & Methyl dehydroabietate & 43.25 & $\mathrm{C}_{21} \mathrm{H}_{30} \mathrm{O}_{2}$ & 2673 & 1.22 \\
\hline 60 & Kolavenol & 46.26 & $\mathrm{C}_{20} \mathrm{H}_{34} \mathrm{O}$ & 2771 & 0.34 \\
\hline 61 & 9-Ethyl-10-methylanthracene & 46.50 & $\mathrm{C}_{17} \mathrm{H}_{16}$ & 2778 & 0.10 \\
\hline 62 & 10,18-Bisnorabieta-5,7,9(10),11,13-pentaene & 47.56 & $\mathrm{C}_{17} \mathrm{H}_{16}$ & 2809 & 0.19 \\
\hline 63 & Retene & 48.65 & $\mathrm{C}_{18} \mathrm{H}_{18}$ & 2836 & 1.12 \\
\hline 64 & n-Hexadecanoic acid & 51.02 & $\mathrm{C}_{16} \mathrm{H}_{32} \mathrm{O}_{2}$ & 2895 & 0.15 \\
\hline & Total & & & & 95.15 \\
\hline
\end{tabular}

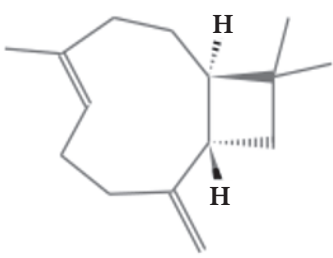

Caryophyllene, $23.73 \%$

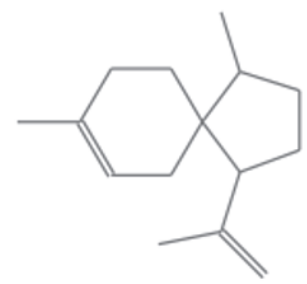

4-epi- $\alpha$-Acoradiene, $4.98 \%$

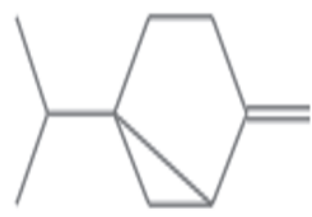

Sabinene, $\mathbf{1 8 . 1 5 \%}$

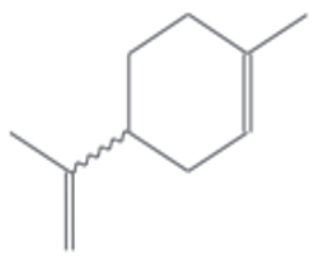

Limonene, $4.92 \%$

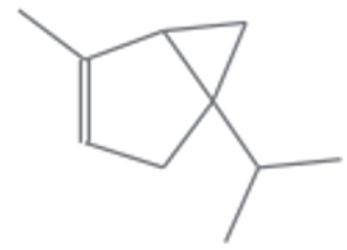

$\alpha$-Thujene, $6.57 \%$

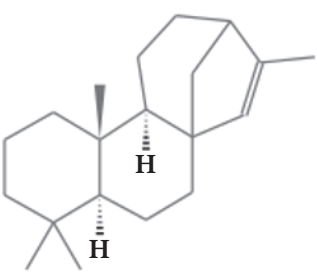

Isophyllocladen, $1.25 \%$

FIGURE 4: The structure of mainly terpenoids in AVO.

properties and targets for the main compounds of AVO (http://lsp.nwu.edu.cn/molecule.php?qn=193). Data showed that caryophyllene and limonene related some autoimmune diseases, genetic diseases, and corresponding targets (supplementary Table 1), such as cardiovascular disease, arthritis, cancer, autoimmune cardiomyopathy, and Parkinson's disease. From the database, we could not correlate the exact relation between AVO active components and vitiligo or melanin loss disease. But according to the database information, we inferred that caryophyllene and limonene has immunomodulatory, antioxidant, and anticancer effects. Hence, we hypothesized that AVO increased melanin biosynthesis may be related to immunomodulatory and antioxidant effect from caryophyllene and limonene.

\section{Conclusions}

According to the biological and chemical analysis of AVO, the AVO can increase melanin synthesis. It be may concluded that terpenoids rich chemical properties of AVO may be responsible for its biological effects.

\section{Data Availability}

Most of the data (Figures 1, 2, and 3 and Table 1) used to support the findings of this study are included within the article. Some of the data (Supplementary Figure 1: GC-MS chromatogram of n-alkanes) used to support the findings of this study are included within the supplementary information file.

\section{Conflicts of Interest}

The authors declare that there are no conflicts of interest regarding the publication of this paper.

\section{Acknowledgments}

This work was supported by the Xinjiang Key Laboratory for Xinjiang Indigenous Medicinal Plants Resource Utilization Grant no. 2016D03027 and funding by the Recruitment Program of Global Expert awarded to Maiwulanjiang. 


\section{Supplementary Materials}

Supplementary Figure 1: AVO prevents cell death in $\mathrm{H}_{2} \mathrm{O}_{2}$ treted B16 cells. Cell viability was measured by a CCK- 8 assay. The data are shown as the means $+\mathrm{SD} ; \mathrm{n}=3$ and $* * * \mathrm{p}$ $<0.001$ compared with control group. Supplementary Figure 2: the GC peak of $n$-alkanes standard. Supplementary Table 1: related diseases and targets of caryophyllene and limonene. (Supplementary Materials)

\section{References}

[1] T. Ito, S. Aimaiti, N. N. Win, T. Kodama, and H. Morita, "New sesquiterpene lactones, vernonilides $\mathrm{A}$ and $\mathrm{B}$, from the seeds of Vernonia anthelmintica in Uyghur and their antiproliferative activities," Bioorganic \& Medicinal Chemistry Letters, vol. 26, no. 6, pp. 3608-3611, 2016.

[2] A. Turak, Y. Liu, and H. A. Aisa, "Elemanolide dimers from seeds of Vernonia anthelmintica," Fitoterapia, vol. 104, pp. 2330, 2015.

[3] R. Lin and Y. L. Chen, "Flora of China," Beijing, China, 1985.

[4] A. Tuerxuntayi, Y.-Q. Liu, A. Tulake, M. Kabas, A. Eblimit, and H. A. Aisa, "Kaliziri extract upregulates tyrosinase, TRP-1, TRP2 and MITF expression in murine B16 melanoma cells," BMC Complementary and Alternative Medicine, vol. 14, no. 5, p. 166, 2014.

[5] Y. J. Wang, F. P. Lin, and L. I. Xm, "Effect observation of qubai babuqi pian combined with tacrolimus ointment in the treatment of vitiligo," Medical Journal of Jilin, vol. 34, no. 4, pp. 637-639, 2013.

[6] Y. T. Liu, W. H. Zeng, and J. W. Wang, "Clinical efficacy of the Qubai Babuqi Tablets in the treatment of vitiligo," Chinese Journal of Aesthetic Medicine, vol. 20, no. 9, pp. 1428-1430, 2011.

[7] D. Y. Song, "Clinical observation on the treatment of vitiligo by Chinese medicine vernonia anthelmintica and Ling Bai combined with narrow band ultraviolet B," Journal of Dermatology and Venereal Disease, vol. 17, no. 1, pp. 41-43, 2010.

[8] Ministry of PRC health and drug standards, Xinjiang, China, 1999.

[9] J. Zhou, J. Shang, F. Ping, and G. Zhao, "Alcohol extract from Vernonia anthelmintica (L.) willd seed enhances melanin synthesis through activation of the p38 MAPK signaling pathway in B16F10 cells and primary melanocytes," Journal of Ethnopharmacology, vol. 143, no. 2, pp. 639-647, 2012.

[10] I. Bukhari, M. Hassan, F. M. Abassi et al., "Antibacterial spectrum of traditionally used medicinal plants of Hazara, Pakistan," African Journal of Biotechnology, vol. 24, no. 4, pp. 8404-8406, 2012.

[11] Z. Iqbal, M. Lateef, A. Jabbar, M. S. Akhtar, and M. N. Khan, "Anthelmintic activity of Vernonia anthelmintica seeds against trichostrongylid nematodes of sheep," Pharmaceutical Biology, vol. 44, no. 8, pp. 563-567, 2006.

[12] N. Jahan, M. Ahmad, F. Mehjabeen, A. B. Amber, and S. Muhammad, "Anti-nociceptive activity of seed extract of Vernonia anthelmintica willd," Pakistan journal of pharmaceutical science, vol. 11, no. 11, pp. 2177-2181, 2014.

[13] S. Jamil, R. A. Khan, S. Ahmed, and S. Fatima, "Evaluation of anti-inflammatory and anti-oxidant potential of seed extracts of Vernonia anthelmintica," Pakistan Journal of Pharmaceutical Sciences, vol. 30, no. 3, pp. 755-760, 2017.
[14] S. S. Fatima, M. D. Rajasekhar, K. V. Kumar, M. T. S. Kumar, K. R. Babu, and C. A. Rao, "Antidiabetic and antihyperlipidemic activity of ethyl acetate: isopropanol (1:1) fraction of Vernonia anthelmintica seeds in Streptozotocin induced diabetic rats," Food and Chemical Toxicology, vol. 48, no. 2, pp. 495-501, 2010.

[15] S. Jamil, R. A. Khan, S. Afroz, and S. Ahmed, "Phytochemistry, Brine shrimp lethality and mice acute oral toxicity studies on seed extracts of Vernonia anthelmintica," Pakistan Journal of Pharmaceutical Sciences, vol. 29, no. 6, pp. 2053-2057, 2016.

[16] G. Tian, U. Zhang, T. Zhang, F. Yang, and Y. Ito, "Separation of flavonoids from the seeds of Vernonia anthelmintica Willd by high-speed counter-current chromatography," Journal of Chromatography A, vol. 1049, no. 8, pp. 219-222, 2004.

[17] Y. X. Wang, E. Wang, S. Jing, and W. Hao, "The chemical composition of caffeoyl quinic acid in Vernonia anthelmintica," China journal of Chinese materia medica, vol. 11, pp. 1590-1592, 2012.

[18] A. Turak, Z. Maimaiti, H. Ma, and H. A. Aisa, "Pseudodisesquiterpenoids from seeds of Vernonia anthelmintica and their biological activities," Phytochemistry Letters, vol. 21, pp. 163-168, 2017.

[19] N. Mamat, J. Dou, X. Lu, A. Eblimit, and A. Haji Akber, "Isochlorogenic acid A promotes melanin synthesis in B16 cell through the $\beta$-catenin signal pathway," Acta Biochimica et Biophysica Sinica, vol. 49, no. 9, pp. 800-807, 2017.

[20] H. J. Kim, J. S. Kim, J.-T. Woo, I.-S. Lee, and B.-Y. Cha, "Hyperpigmentation mechanism of methyl 3,5-di-caffeoylquinate through activation of p38 and MITF induction of tyrosinase," Acta Biochimica et Biophysica Sinica, vol. 47, no. 7, pp. 548-556, 2015.

[21] L. Yin, C. Niu, L.-X. Liao, J. Dou, M. Habasi, and H. A. Aisa, "An isoxazole chalcone derivative enhances melanogenesis in b16 melanoma cells via the Akt/GSK3 $\beta / \beta$-catenin signaling pathways," Molecules, vol. 22, no. 12, pp. 1-12, 2017.

[22] R. Baron, M. Zayats, and I. Willner, "Dopamine-, L-DOPA-, adrenaline-, and noradrenaline-induced growth of Au nanoparticles: Assays for the detection of neurotransmitters and of tyrosinase activity," Analytical Chemistry, vol. 77, no. 6, pp. 1566-1571, 2005.

[23] W. Li, B. Hong, Z. Li, Q. Li, and K. Bi, "GC-MS method for determination and pharmacokinetic study of seven volatile constituents in rat plasma after oral administration of the essential oil of Rhizoma Curcumae," Journal of Pharmaceutical and Biomedical Analysis, vol. 149, pp. 577-585, 2018.

[24] Y. G. Wang, X. Y. Wei, H. L. Yan, Z. K. Li, S. K. Wang et al., "Identification of unknown organosulfur compounds with GC/QTOF-MS in the water-soluble portion from mildly oxidized Jincheng No. 15 anthracite," Fuel, vol. 135, no. 7, pp. 188190, 2014

[25] P. Zheng, Y. Wang, H. M. Lu, X. Y. Zhou et al., "Plasma Metabolomics Analysis Based on GC-MS in Infertile Males with Kidney-Yang Deficiency Syndrome," Evidence-Based Complementary and Alternative Medicine, vol. 2017, Article ID 6270195, 11 pages, 2017.

[26] M. K. Swamy, G. Arumugam, R. Kaur, A. Ghasemzadeh, M. M. Yusoff, and U. R. Sinniah, "GC-MS Based Metabolite Profiling, Antioxidant and Antimicrobial Properties of Different Solvent Extracts of Malaysian Plectranthus amboinicus Leaves," Evidence-Based Complementary and Alternative Medicine, vol. 2017, Article ID 1517683, 10 pages, 2017. 
[27] L. Guerra, E. Dellambra, S. Brescia, and D. Raskovic, "Vitiligo: pathogenetic hypotheses and targets for current therapies," Current Drug Metabolism, vol. 11, no. 5, pp. 451-467, 2010.

[28] T. Pei, C. Zheng, C. Huang et al., "Systematic understanding the mechanisms of vitiligo pathogenesis and its treatment by Qubaibabuqi formula," Journal of Ethnopharmacology, vol. 190, pp. 272-287, 2016.

[29] K. Ezzedine, V. Eleftheriadou, M. Whitton, and N. van Geel, "Vitiligo," The Lancet, vol. 386, no. 9988, pp. 74-84, 2015.

[30] W.-W. Chao, C.-C. Su, H.-Y. Peng, and S.-T. Chou, "Melaleuca quinquenervia essential oil inhibits $\alpha$-melanocyte-stimulating hormone-induced melanin production and oxidative stress in B16 melanoma cells," Phytomedicine, vol. 34, pp. 191-201, 2017.

[31] X.-M. Liu, Q. Zhou, S.-Z. Xu, K. Wakamatsu, and T.-C. Lei, "Maintenance of immune hyporesponsiveness to melanosomal proteins by DHICA-mediated antioxidation: Possible implications for autoimmune vitiligo," Free Radical Biology \& Medicine, vol. 50, no. 9, pp. 1177-1185, 2011.

[32] J. M. Richmond, M. L. Frisoli, and J. E. Harris, "Innate immune mechanisms in vitiligo: danger from within," Current Opinion in Immunology, vol. 25, no. 6, pp. 676-682, 2013.

[33] Z.-M. Hu, Q. Zhou, T.-C. Lei, S.-F. Ding, and S.-Z. Xu, "Effects of hydroquinone and its glucoside derivatives on melanogenesis and antioxidation: biosafety as skin whitening agents," Journal of Dermatological Science, vol. 55, no. 3, pp. 179-184, 2009.

[34] Y. Yang, S. Li, G. Zhu et al., "A similar local immune and oxidative stress phenotype in vitiligo and halo nevus," Journal of Dermatological Science, vol. 87, no. 1, pp. 50-59, 2017.

[35] L. Qiu, Z. Song, and V. Setaluri, "Oxidative stress and vitiligo: the Nrf2-ARE signaling connection," Journal of Investigative Dermatology, vol. 134, no. 8, pp. 2074-2076, 2014.

[36] H. Xie, F. Zhou, L. Liu et al., "Vitiligo: How do oxidative stress-induced autoantigens trigger autoimmunity?" Journal of Dermatological Science, vol. 81, no. 1, pp. 3-9, 2016.

[37] S. S. Dahham, Y. M. Tabana, M. A. Iqbal et al., "The anticancer, antioxidant and antimicrobial properties of the sesquiterpene $\beta$-caryophyllene from the essential oil of Aquilaria crassna," Molecules, vol. 20, no. 7, pp. 11808-11829, 2015.

[38] S. M. Adekenov, "Sesquiterpene lactones with unusual structure, Their biogenesis and biological activity," Fitoterapia, vol. 121, no. 6, pp. 16-30, 2017.

[39] A. Ludwiczuk, K. Skalicka-Woźniak, and M. I. Georgiev, "Chapter11: Terpenoids," Pharmacognosy: Fundamentals, Applications and Strategy, pp. 233-266, 2017. 


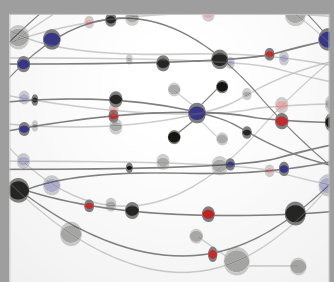

The Scientific World Journal
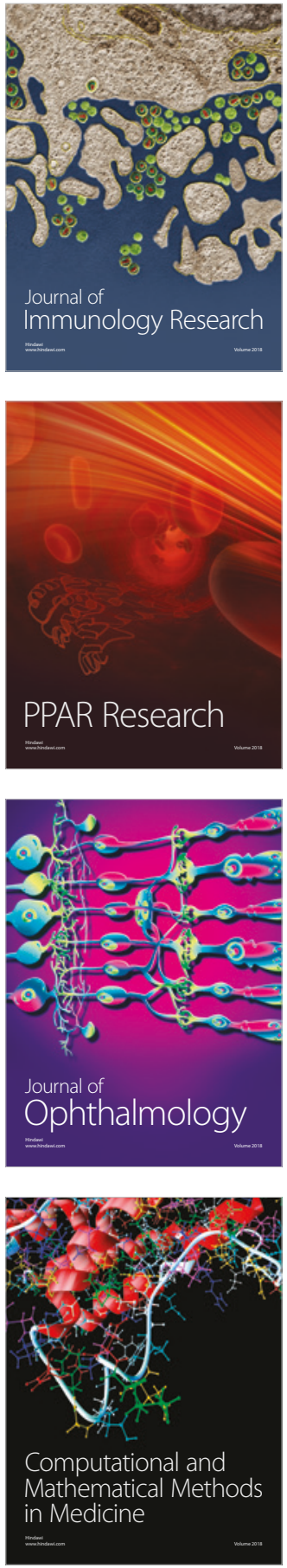

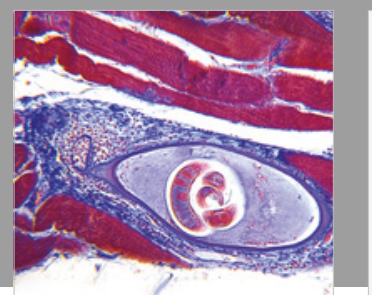

Gastroenterology Research and Practice

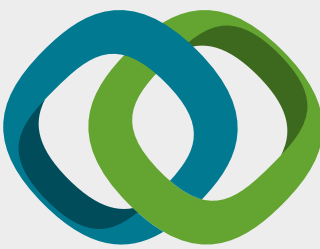

\section{Hindawi}

Submit your manuscripts at

www.hindawi.com
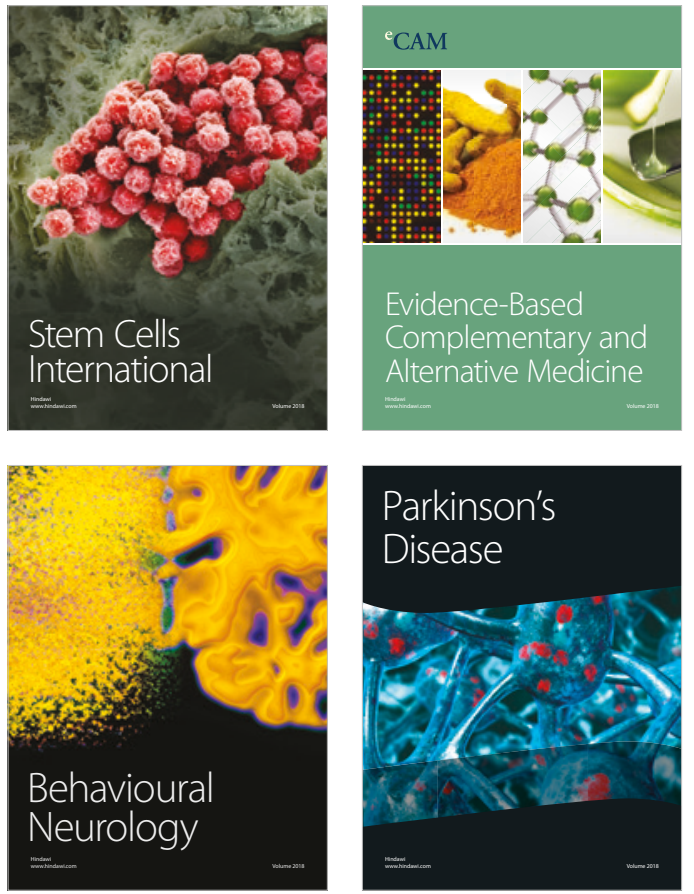

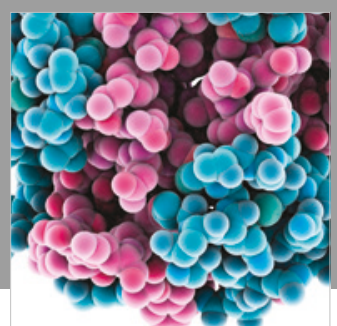

ournal of

Diabetes Research

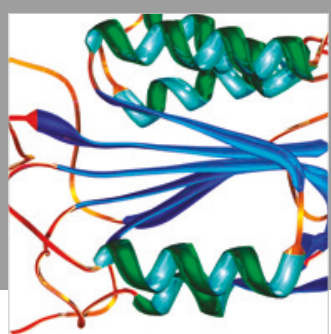

Disease Markers
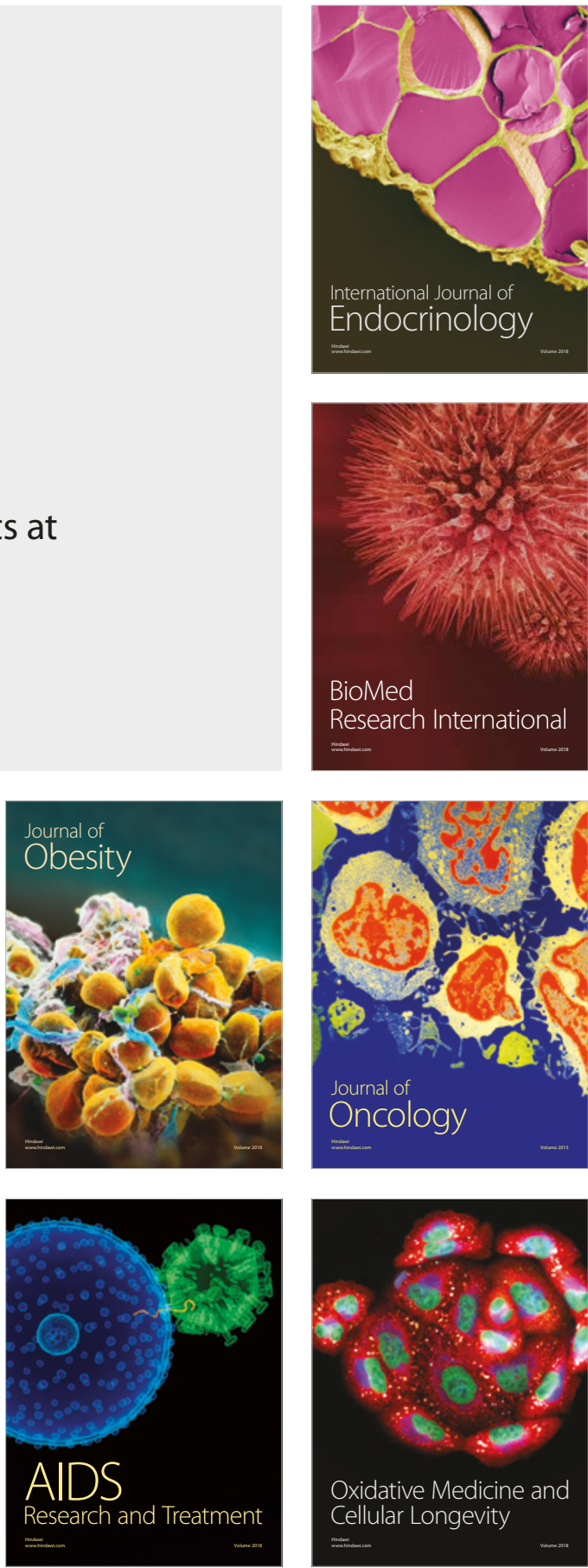